\section{Red eyes first sign of the sickle cell disease}

\author{
Rodrigo Martín Torres, \\ Pablo Gabriel Lódolo \\ Centro De Ojos Dr. Lódolo, Entre Rios, \\ Paraná
}

\begin{abstract}
A patient with red eyes and ocular decongestants drops (tetrahidrozolyne 0.05\%) use history, was observed by an optometrist and referred to an ophthalmic consult. The redness of their eyes was secondary to conjunctival vessel micro-hemorraghe (petechiaes). After a complete ophthalmology and hematologist exploration a Cell Sickle Disease was diagnosed as the cause of the vascular disorder. An hematologist treat it and the ocular redness was resolved. This case emphasizes the problem about self-medication and remark the importance of the optometrist working together with the ophthalmologist to prevent ocular complains as well as systemic disease.
\end{abstract}

\section{Introduction}

There is a long list of pathologies that could produce the redness of the eye. ${ }^{1}$ Although most of them are benign, it is important their classification, because sometimes could be produce it by a herald a vision-threatening or even lifethreatening disorders. ${ }^{1-4}$ There are drops which contain sympathomimetic amines (as example: thetraydrozoline, nafazoline or oxymetazoline), drugs which produce conjunctival vessels vasoconstriction. But whiten the eyes could hide a problem and delay the possibility to establish the correct diagnosis. ${ }^{2}$ Moreover, topical and systemic (cardio-vascular) side-effects and toxicity could be produced. ${ }^{2,4}$ The chronic use of those drops will produce a pharmacological effect called tachyphylaxis: to produce the same effect is necessary a more frequent instillation to control the redness and this will increase the possibility to suffer side effects. ${ }^{5}$

Their use in ophthalmic procedures are limited as diagnostic test and when is necessary to have an extra vasoconstrictor effect in different ocular inflammation disorders, but long time use it is not recommended. The following brief report will describe the case about a young man with chronic red eyes due to unknown systemic disease and chronic use of thetraydrozoline $0.05 \%$ eye-drops.

\section{Case Report}

A young man (26-year-old) came to the consult, referred from a local optometrist, because of a long history of red eyes. The patient said that he has been suffering from red eyes since seven years ago. He never went to an ophthalmologist, but usually used drops (several times a day to whiten his eyes). The drops were recommended in the past for a friend, and they worked for a while but then stopped working and his eyes remain red all the day. The drops used by the patient contain thetrahydrozoline $0.05 \%$. He has no history about systemic disease. He did not smoke, nor consume drugs and the redness began after he woke up lasting all day, without any ocular symptoms. Visual acuity without correction was $20 / 20$ in both eyes. Slit-lamp biomicroscopy shows little red dots (petechiae) around the limbus (Figure 1) and marked dilated vessels (Figure 2) in both eyes. Lids, cornea, anterior chamber, intraocular pressure and fundus were within normal limits, without retinal vascular alteration.

The first diagnosis was ocular surface toxicity due to the vascular rebound effect of the topical decongestants chronic use (dilated conjunctival vessels). The patient was advised about the dangerous effect of those drops and topical treatment with loteprednol etabonate $0.5 \%$ (four times per day) and artificial tears (carboxymethylcellulose $0.5 \%$ ) several times a day were indicated. Moreover, the patient was referred to perform a clinical control, in order to evaluate cardiovascular diseases (to rule out high blood pressure and haematological diseases, mainly vasculitis).

The arterial tension was normal (120/80 $\mathrm{mmHg}$ ) and one week after, the patient came again with a medical report from the clinician with the diagnosis of the Sickle Cell Disease. This is a blood disease; caused by an inherited abnormal hemoglobin. ${ }^{6}$ Distorted red blood cells are fragile and prone to rupture (hemolysis and anaemia) and also can block blood vessels causing tissue and organ damage ${ }^{6}$ (the sign observed at slit-lamp in the conjunctiva, as red dots). Also, the retina could be seriously affected by vascular changes (non-proliferative and proliferative sickle retinopathy), which could lead to vitreous haemorrhage and retinal detachment. ${ }^{\text {? }}$

A haematologist helped the patient to control the disease. There are different treatments for the Sickle Cell Disease, this patient was treated with hydroxyurea therapy. ${ }^{8}$ In this case the retina was not affected and ocular manifestation were just related with the conjuntival vessels. With the treatment, conjunctival petechiaes disappeared and eyes turned white. After eighteen months the patient is only using artificial tears and keep his ocular control every six months, because he has an
Correspondence: Rodrigo M Torres, Las Calandrias 4789 Barrio Las Acaias, Colonia Avellaneda, 3107, Entre Ríos, Argentine.

Tel: +54.343.4317022.

E-mail: romator7@hotmail.com

Key words: decongestants, anemia, conjunctiva.

Contributions: the authors contributed equally.

Conflict of interest: the authors report no conflicts of interest.

Received for publication: 12 August 2011. Accepted for publication: 10 October 2011.

This work is licensed under a Creative Commons Attribution NonCommercial 3.0 License (CC BYNC 3.0).

(C) Copyright R.M. Torres and P.G. Lódolo, 2011

Licensee PAGEPress, Italy

Optometry Reports 2011; 1:e1

doi:10.4081/optometry.2011.e1

increased risk to developed ocular disease related with the Sickle Cell Disease. Moreover, he is under haematological follow up.

\section{Conclusions}

Optometrists frequently are the first to contact with people with or without eye problems. As in this case, their recommendation helps to prevent possible eye complications that can

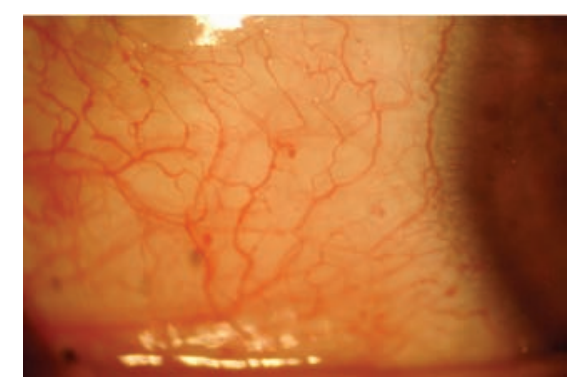

Figure 1. Conjunctival petechiaes.

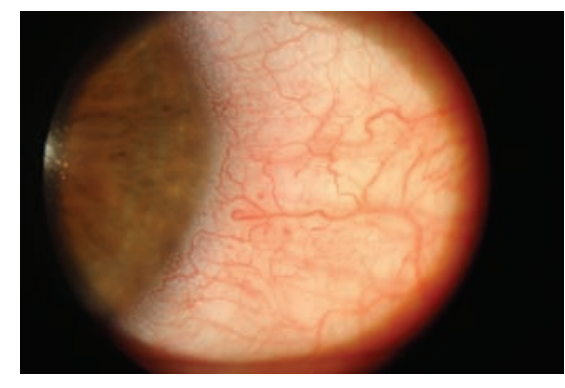

Figure 2. Conjunctival petechiaes and dilated vessels. 
induce blindness and also to detect systemic disease. Red eyes always are related with any ocular complain, sometimes could be a benign condition but others could be a serious disease. The patient must be correctly explored, including an eye detail examination; a differential diagnosis and if a problem is suspected, patient must be referred to perform an ophthalmic consult to obtain a definitive diagnosis and treatment if it is necessary. Decongestants drops must be indicated whit caution because their effect could hide a problem that could be a severe ocular or systemic illness like in the case reported. In the presented case, red eyes due to conjunctival petechiaes were the leading sign that permit the diagnosis of the Sickle Cell Disease.

\section{References}

1. Leibowitz HM. The red eye. N Engl J Med 2000;343:345-51.

2. Tappeiner C, Sarra GM, Abegg M. Abuse of vasoconstrictive eyedrops mimicking an ocular pemphigoid. Eur J Ophthalmol 2009;19:129-32.

3. Xuan B, Chiou GC. Efficacy of oxymetazoline eye drops in non-infectious conjunctivitis, the most common cause of acute red eyes. J Ocul Pharmacol Ther 1997;13:363-7.

4. Spiller H, Griffith J. Prolonged cardiovascular effects after unintentional ingestion of tetraydrozoline. Clin Toxicol (Phila)
2008;46:171-2.

5. Ramey JT, Bailen E, Lochey RF. Rhinitis medicamentosa. J Investig Allergol Clin Immunol 2006;16:148-55.

6. Rahimi Z, Parsian A. Sickle cell disease and venous thromboembolism. Mediterr $\mathrm{J}$ Hematol Infect Dis 2011;3:e2011024.

7. Penman AD, Talbot JF, Chuang EL, et al. New classification of peripheral retinal vascular changes in sickle cell disease. $\mathrm{Br}$ J Ophthalmol 1994;78:681-9.

8. Torres AF, Eberle SE, Sciuccati G, Bonduel M. Effect of hydroxyurea on hemoglobin S. Medicina (B Aires) 2003;63:140-2. 